\title{
THE TECTONO - STRATIGRAPHIC EVOLUTION OF PINDOS FORELAND EAST OF MESOLONGI
}

\author{
Noti A. ${ }^{1}$, Tserolas P. ${ }^{1}$, Maravelis A. ${ }^{2}$ and Zelilidis A. ${ }^{1}$ \\ ${ }^{1}$ Department of Geology, University of Patras, Patra, 26110, Greece \\ ${ }^{2}$ School of Environmental and Life Sciences, University of Newcastle, Callaghan 2308 NSW, \\ Australia,Angelos.Maravelis@newcastle.edu.au
}

\begin{abstract}
Sedimetological analysis of submarine fan deposits, both north and south of Evinos River, east of Mesolongi town, showed that there are different sedimentological conditions. The southern part outcropped between Klokova and Varasova Mountains, influenced by Gavrovo thrust activity, is characterized by coarse grained inner fan deposits, and sourced both from Pindos chain and the uplifted Klokova and Varasova Mountains. Gavrovo thrust activity, took place during the sedimentation producing intrabasinal highs, changing basin geometry. In the northern part, where outer fan deposits passes upwards to inner fans, there is no obvious influence of Gavrovo thrust but mostly the influence of internal Ionian Thrust. Between the two studied areas there is a high deformed area, about $1 \mathrm{~km}$ wide, trending parallel to the Evinos River in a ENE direction, showing that probable Evinos River flows on a strike-slip fault.

Keywords: Evinos River, Gavrovo Thrust, Klokova and Varasova mountains,
\end{abstract} submarine-fans.

\section{Пєрí $\eta \psi \eta$}

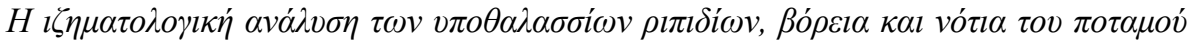

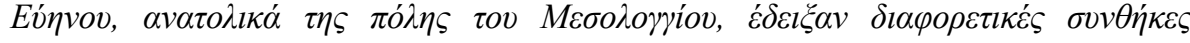

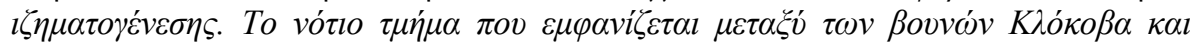

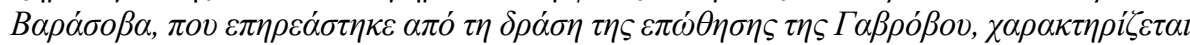

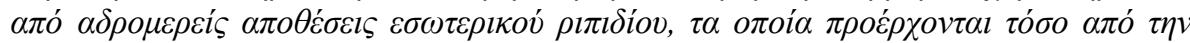

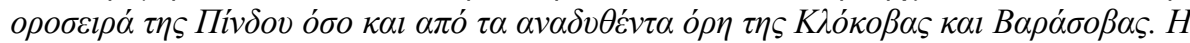

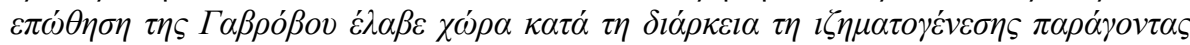

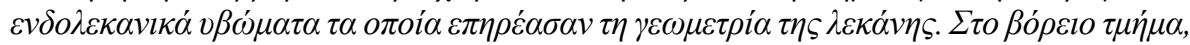

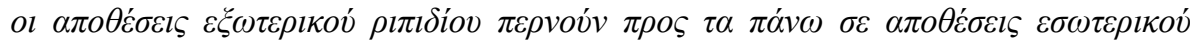

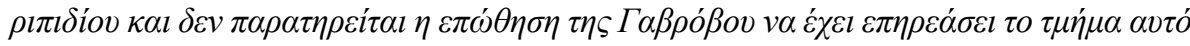

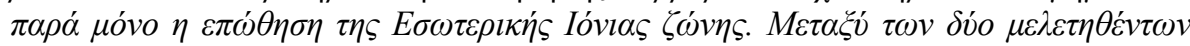

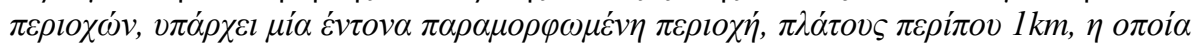

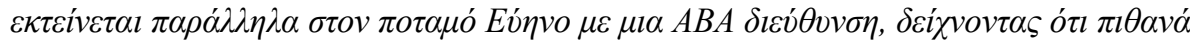

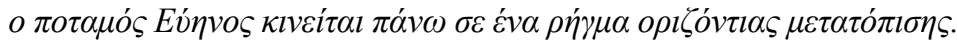

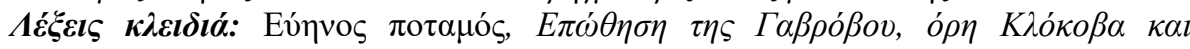

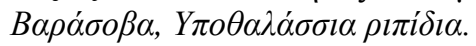




\section{Introduction}

Pindos foreland deposits (Fig. 1) have been interpreted as submarine fan deposits, sourced from the Pindos thrust belt to the east (for reference see Avramidis et al., 2000). The accumulation of the submarine-fans resulted from the deformation of the external Hellenides which migrated in a westward direction. During this migration, on the Gavrovo and Ionian zones Pindos foreland was formed (for reference see Zelilidis et al., 2015).

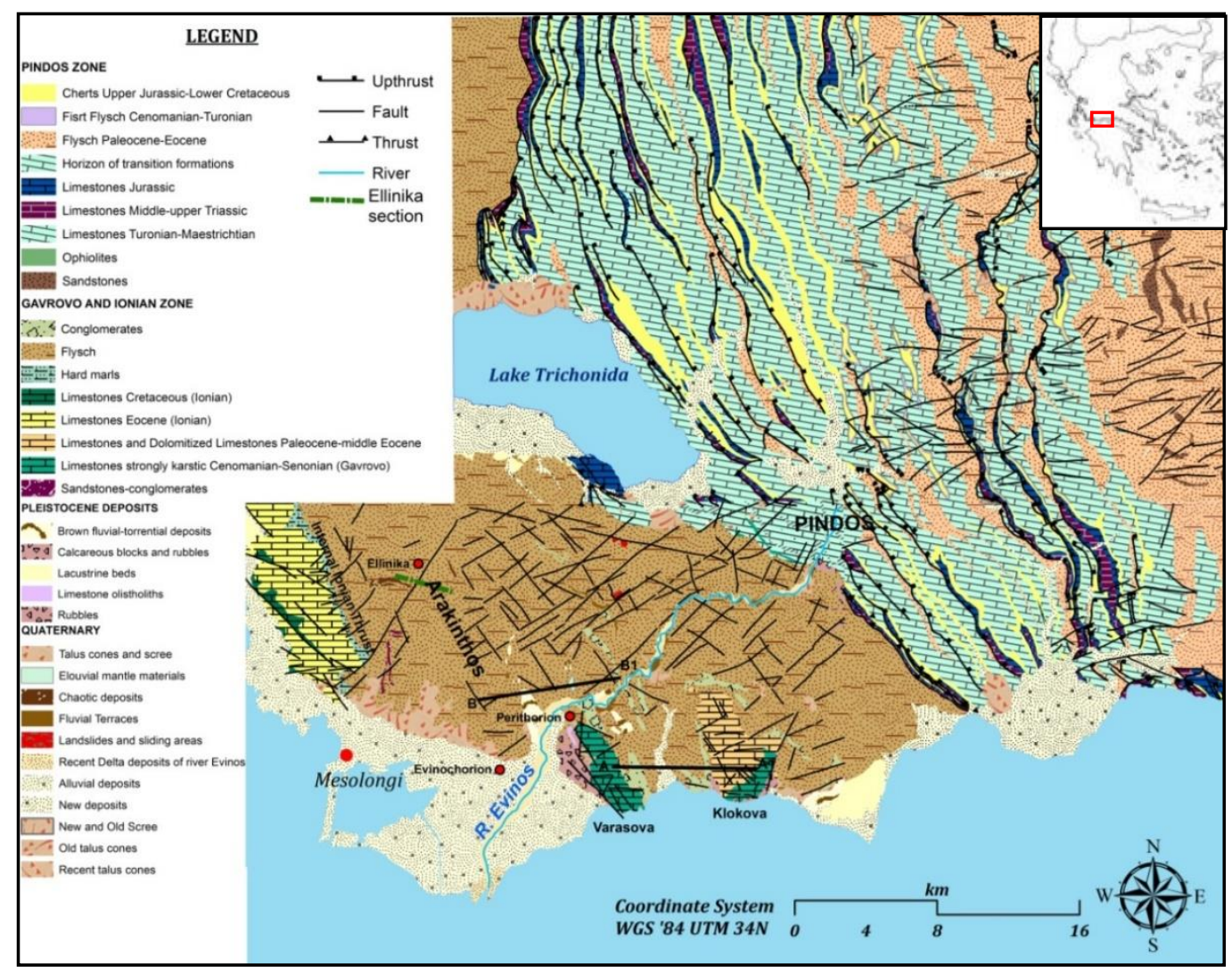

Figure 1 - Geological map of south Aitoloakarnania compared to the Greek space (modified from IGME Geological maps 1:50.000 sheets Messolonghion, Evinokhorion, Nafpaktos, Klepa, Thermon).

The age of Pindos foreland according to Avramidis et al. (2002) is different along the basin ranging from middle Eocene to early Miocene. Pindos foreland was affected by the presence of internal thrusting and transfer faults, causing changes in depth and width. Due to internal thrusting (Gavrovo, internal and middle Ionian thrusts), creating intrabasinal highs that influenced palaeocurrent directions (Avramidis and Zelilidis, 2001; Konstantopoulos et al., 2013). Transfer faults cross-cut the intrabasinal highs and produced low relief areas that act as pathways for sediment distribution.

In this work a restricted area of the Pindos Foreland, east of Mesolongi, was studied. Sedimentological analysis led us to construct and to introduce the basin evolution model. Combination of the field data led us to identify the differences between the south and the north part of the basin, separated by the Evinos River. 


\section{Geological setting}

Vakalas et al. (2004) described the Ellinika section in the western end of the studied area where he found a late Eocene to late Oligocene age of submarine fans for the western part of Arakinthos Mountain (Fig. 2). According to Vakalas and Zelilidis (2002) the Ellinika section, shows a measured stratigraphic thickness of $2000 \mathrm{~m}$. From the base to the top of the stratigraphic column the following environments have been identified: A. Outer fan deposits consisting of lobe and lobe fringe deposits ( $600 \mathrm{~m}$ thick). At the base of this sequence near the contact with the Eocene limestone thick calcareous turbidites have been recognized. B. Inner fan deposits $(1200 \mathrm{~m})$ comprising channels and levee/interchannel deposits. At the lower stratigraphic positions of the Ellinika sections, the paleoflow direction is mainly towards the west. In the middle stratigraphic levels, the paleoflow regime changes parallel to the basin axis direction. Considering that at these levels inner fan deposits have been recognized, it seems that the geometry of the basin must have been changed to a more trough-like character, where the flows were controlled by the confinement which is caused by the trough. At the western margins of the section, some easterly flow directions have been observed, suggesting an increase of the sea floor gradient due to the activation of the Internal Ionian thrust. The activity of the thrust would have increased the instability in this area, triggering submarine failures.

Proposed paleogeographic evolution introduced that clastic sedimentation began during late Eocene; whereas the transition from the chemical to clastic sedimentation seems to have been abrupt. Later, and during upper Eocene to lower Oligocene the basin configuration changed to well-expressed trough geometry. This change is supported by the turn of the paleoflow trend to an axial direction. Also, the outer fan deposits which were deposited during the previous period of the evolution appear tectonically deformed, suggesting the influence of a tectonic event, such as the activation of the Gavrovo and Internal Ionian thrusts. Finally, during Oligocene inner fan deposits were accumulated showing a decrease of the system's energy and a westward migration of the tectonic activity.

\section{Facies analysis and facies associations of the studied area}

The studied submarine fan deposits east of Mesolongi (Fig. 2) subdivided into 4 regions, 2 north and 2 south of the Evinos river, the area between Klokova and Varasova (region A), the area of Perithori and Evinos (region B), the Arakinthos mountain (region C) and the area east of Arakinthos (region D). Stratigraphic columns for these different regions are presented on figure 3. Sedimentological analysis led us to organize lithologies into 4 facies:

Facies 1: mudstone-sandstone interbeds with fine-grained, thin-bedded sandstones (bed thickness 2$5 \mathrm{~cm}$ ) and mudstone beds. Rarely sandstone beds with $20-50 \mathrm{~cm}$ thick occur.

Facies 2: Sandstone-mudstone interbeds with fine-grained to medium-grained sandstone beds, 20$50 \mathrm{~cm}$ thick, and mudstone beds with the same thickness.

Facies 3: Sandstone, with medium-grained to coarse-grained sandstone beds, $80-150 \mathrm{~cm}$ thick. On the top of sandstones thin mudstones are present, decreasing or lacking when amalgamation of successive sandstone beds is observed. In the area of Arakinthos, a micro-breccia-conglomeratic bed with normal graded bedding occurs within these facies.

Facies 4: Conglomerates which consist mainly of well-rounded limestone cobbles into sandstone matrix. 


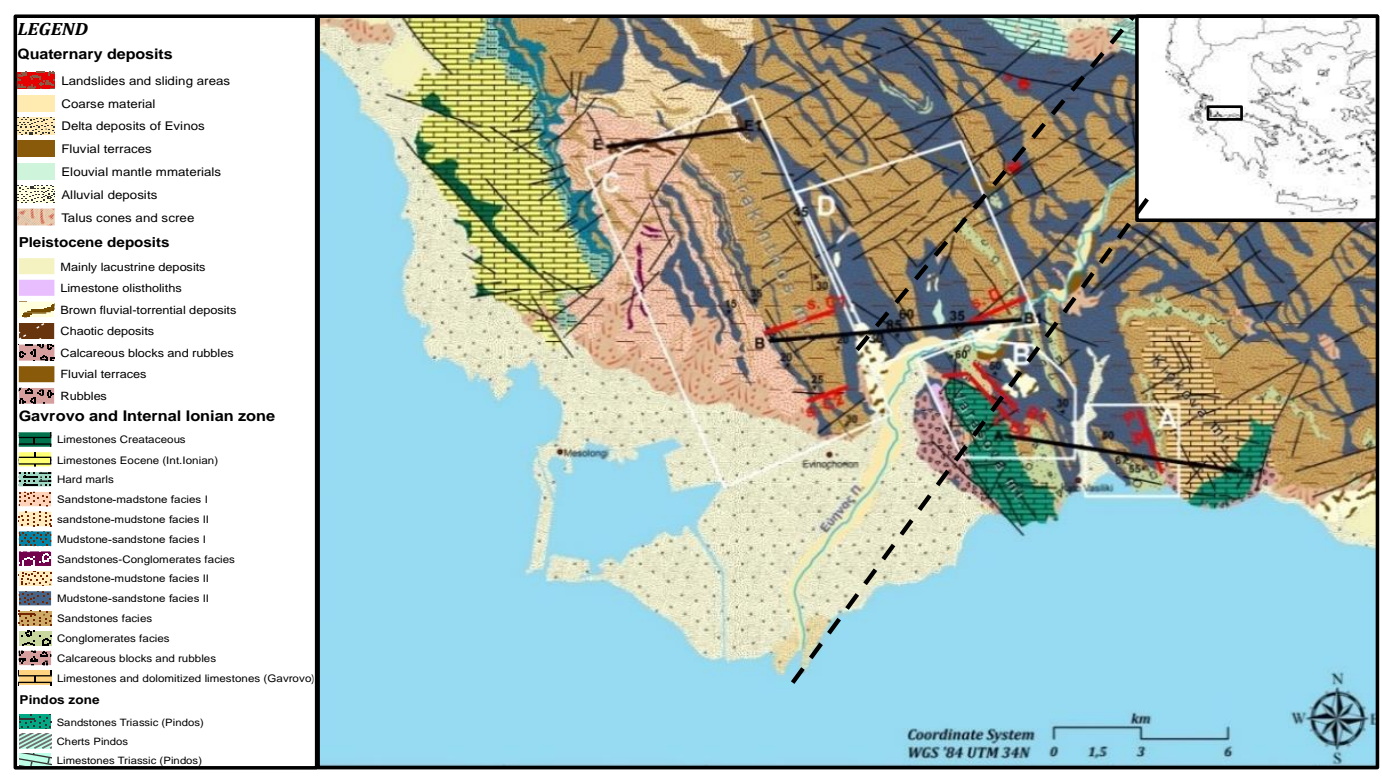

Figure 2 - Geological map which shows the studied regions (a synthesis from geological maps of IGME sheets Evinokhorion 1991 and Messolonghion 1996).

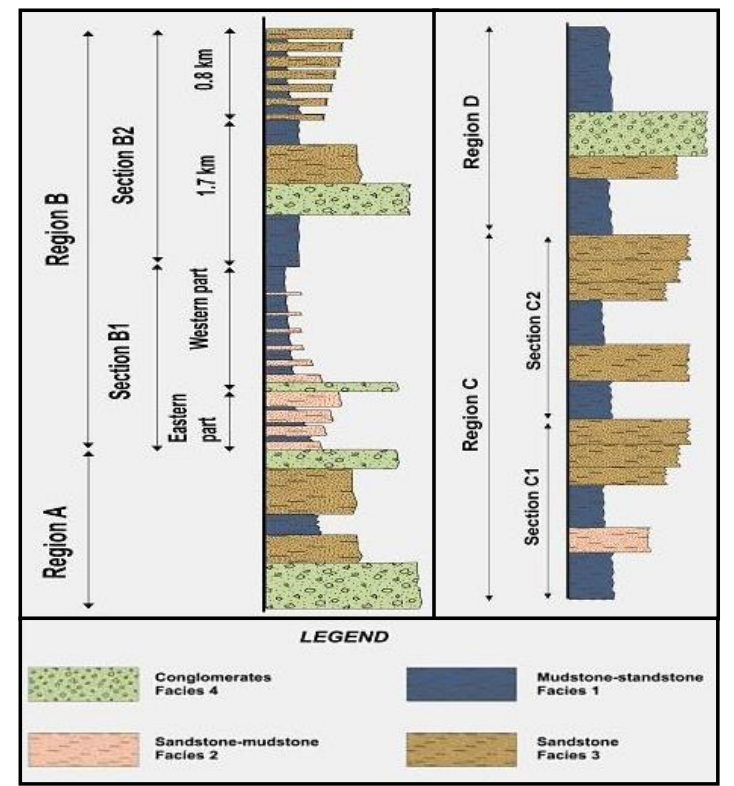

Figure 3 - Synthetic columns of the constructed sections for the regions A and B and C and D. 


\subsection{South of the river Evinos}

This area was studied in two regions, region A and region B (Fig.2).

Region A: is characterized by the presence of cemented conglomerates, up to $200 \mathrm{~m}$ thick and $1 \mathrm{~km}$ long (facies 4, on section A of region A, on figure 2) with interbedded sandstone beds (facies 3 ) and thin mudstone-sandstone beds (facies 1). The sandstone base of facies 3 is flat with good lateral continuity. Facies 1 in this region is outcropped as a slump horizon within facies 4 (Fig. 4A) showing that large blocks of facies 4 could slide using as a sliding surface of hyper pressured or fluidized mudstones (facies 1). The deposition of thick bedded sandstones (facies 3) took place due to rapid deposition of a high density turbiditic current. The above deposits of region A represent channel-fill deposits accumulated in an inner fan environment.

Region B: Deposits of this region, with up to 400m thickness, can be divided into two sections, B1 and B2, $1 \mathrm{~km}$ and 2,5km long, respectively. The B1 is stratigraphically below B2.

Section B1: From east to west, in an up to 340m long part of the section, facies 1, facies 4 and facies 2 were recognized. Facies 4 is characterized by erosional base and channelized geometry (Fig. 4B). Conglomerates are massive with sand matrix and a total thickness up to $4,5 \mathrm{~m}$. The pebbles size varies from 2-10cm and consists of limestones: 60\%, sandstones: $30 \%$ and cherts: $10 \%$. Facies 2 is characterized by an upward coarsening and thickening of sandstone beds introducing outer fan lobe deposits.

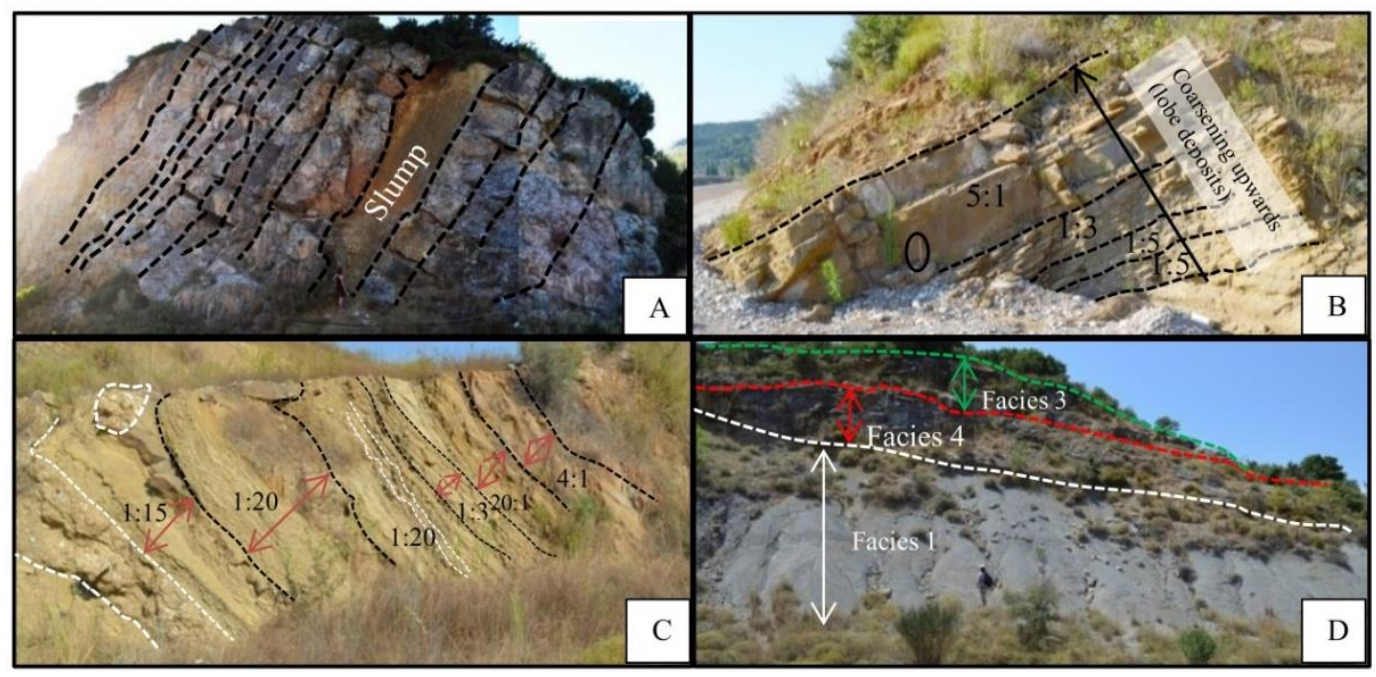

Figure 4 - A) Geological section of facies 4 in alternation with facies 3 and facies 1. B) Part of the section $B 1$ which shows the upgrading and the increase of sandstones' thickness upward (lobe deposits). C) Western edge of section B1 expressed with channel and levee deposits. D) Part of section B2 which shows the base of the sequence (facies 1), in the middle the facies 4 and on top the facies 3 .

At the western part of this section at least 6 cycles with interbedded facies 2 with facies 1 are present, whereas and only in the upper two cycles facies 4 also is present (Fig. 4C), at the base of each cycle. In facies 2 the sandstone beds show an upward decrease both on bedding thickness and on particle size. So, from the above we can suggest for the western part of this section a middle fan environment where channel-fill deposits were accumulated, whereas fine-grained sediments could represent levee deposits.

Section B2: This S-N section and from older to younger deposits, for a distance of $1,7 \mathrm{~km}$, is characterized by facies 1 at the base, facies 4 in the middle part, facies 3 in the upper part (Fig. 4D) 
and facies 1 in the uppermost part. Northwards the rest section (for about $800 \mathrm{~m}$ distance) is characterized by thick interbedded of facies 1 with facies 3 . The difference between these two parts of Section B2 is that the in lower part facies 3 is characterized by erosional bases and fining and thinning upwards of sandstone beds, whereas in the upper part facies 3 is characterized by flat bases, lateral extension, and coarsening and thickening upward. So, the lower part with facies 1, 3 and 4 is interpreted as channel fill deposits in an inner fan environment and the upper part as lobe deposits in an outer fan environment.

\subsection{North of the river Evinos}

North of the river Evinos area was studied in two regions, C and D (Fig. 2).

Region $\mathrm{C}$ : The submarine fan deposits of region $\mathrm{C}$ have been studied in two sections, $\mathrm{C} 1$ and $\mathrm{C} 2$. The $\mathrm{C} 1$ is stratigraphically below $\mathrm{C} 2$.

Section C1: This section is subdivided into two sedimentary cycles. The lower cycle is constituted by facies 1 which pass upwards to facies 2, whereas the upper cycle with facies 1 at the lower part pass upwards to facies 3. Each cycle is characterized by coarsening and thickening upward in sandstone beds, up to $80 \mathrm{~cm}$ thick, and s/m ratio changes from $1 / 1$ and finally to $9 / 1$. Facies 2 and 3 are characterized by flat bases and lateral extend. So, facies 2 and 3 are interpreted as lobe deposits and facies 1 as levee deposits.

Section C2: This section is subdivided into two sedimentary cycles with facies 1 at the lower part of each cycle and facies 3 in each upper part. Each cycle is characterized by coarsening and thickening upward in sandstone beds and s/m ratio changes from 1/9 to 1/1 and finally to 9/1. Facies 3 is characterized by flat bases and lateral extend (Fig. 5A). Facies 1 in the lower part is thinly interbedded whereas in the upper cycle sandstone beds are up to $10-15 \mathrm{~cm}$. So, facies 3 is interpreted as lobe deposits, facies 1 in the lower cycle as interlobe-lobe fringe, whereas in the upper cycle as levee deposits.

Region D: This region is characterized by strong deformed sediments, and this deformation is restricted only in this region. The submarine fans of area $\mathrm{D}$ are characterized mostly by facies 1 , and only in some places facies 3 and facies 4 are present over facies 1 either with fault controlled contacts (Fig.5B) or with angular unconformity (5C). It seems that facies 1 with thinly bedded mudstones accumulated in a basin plain environment, represents the lower stratigraphic sediments of the studied area and outcropped due to internal thrusting (Gavrovo thrust?). Facies 3 and 4 are characterized by erosional bases, channelized geometries (Fig. 5C), and showing channel-fill deposits in an inner fan environment. Facies 3 sandstones, of submarine fans, are characterized by Bouma subdivisions Ta, $\mathrm{Tb}$ and $\mathrm{Tc}$ and amalgamation surfaces indicating a medium to high energy environment (Fig. 5D). The relation between facies 1 with facies 3 and 4 suggests that there was a synsedimentary deformation of this part of the basin explaining the unconformity and the fault controlled contacts. 


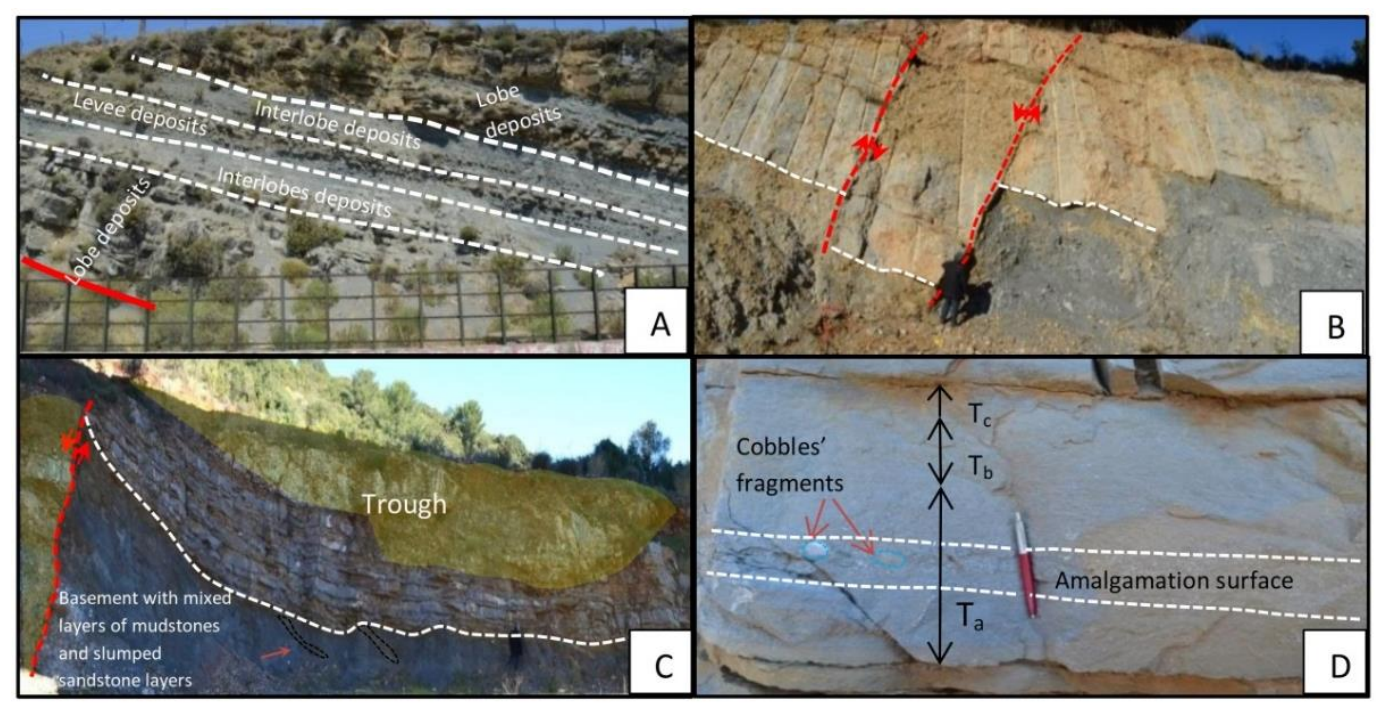

Figure 5 - A) Part of section C2, expressed with outer fan lobe deposits, levee deposits and interlobe deposits. B) Conglomerates overlying the basement. We also see faults responsible for basement's emersion. C) Channel deposits lying above of the basement. D) Sandstone layer with amalgamation surface and the Bouma sequence.

\section{Paleocurrent directions}

Palaeoccurent regime, based on measured traces (groove marks), showed a northward trend for areas $\mathrm{A}$ and $\mathrm{B}$, indicating an axial transporting regime, whereas the main paleocurrent direction of the region $\mathrm{C}$ (Arakinthos mountain) is NW-SE and the main direction of the area D is towards the west.

\section{Paleogeographic evolution}

Studied area is organized into two evolutionary stages.

Stage A: During Upper Eocene (Fig. 6A) clastic sedimentation starts in the study area at the part northern of the river Evinos, expressed with basin plane deposits. The transition is characterized by thick turbiditic limestones, indicating a stronger instability regime of the western margin of the basin in this part. Meanwhile, during the same period starts the deposition of submarine fans at the part south of river Evinos, which is also expressed with basin plane deposits.

Stage B: During Oligocene (Fig. 6B) outer fan lobes were deposited north of river Evinos and specifically in areas $\mathrm{C}$ and $\mathrm{D}$ channel deposits dominate. At the South because of Gavrovo ridge the relief of the bottom of the basin is directly affected with the deposits in the regions A and B characterized as inner fan deposits with deposition of the coarser material nearby the ridges of Klokova and Varasova. Furthermore, the Pindos overthrust seems to be still active as paleocurrent directions in the north showed NE-SW. Finally, during the Lower Oligocene shallowing of the basin continues while Pindos thrust is gradually inactivated and pressure migrates towards the west converting the basin into a piggy back basin. 


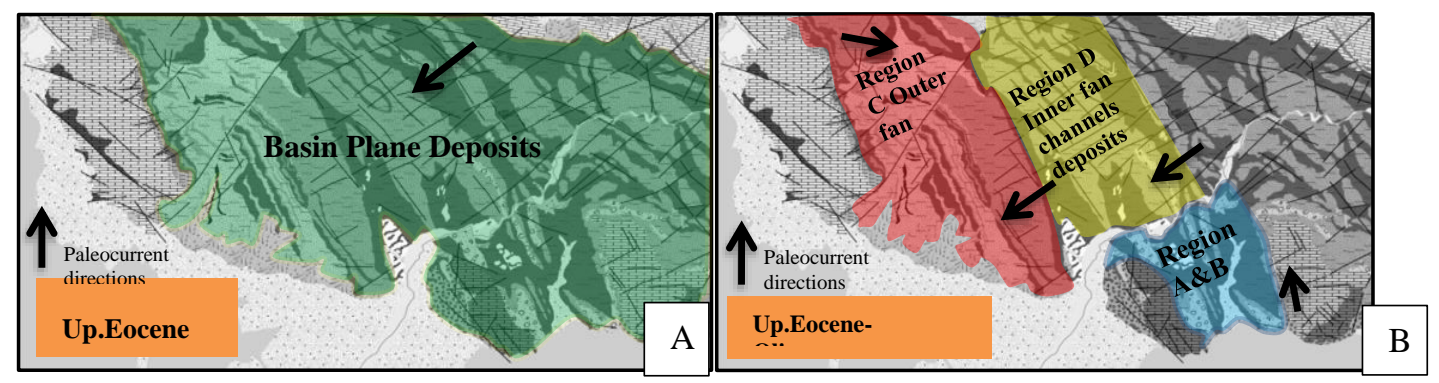

Figure 6 - A) Map which shows the paleogeographic evolution in the Upper Eocene. B) Map which shows the paleogeographic evolution in the period of Upper Eocene-Oligocene.

\section{Conclusions}

Studied area is characterized by the evolution of submarine fans. In detail, in both areas basin plain deposits were accumulated during late Eocene, but after this stage they had different evolution.

During Oligocene the northern area (Fig. 7) is characterized by more dipper and distal conditions than the southern area. In the northern area outer fan lobes were deposited, whereas in the southern area inner fan channel deposits were accumulated, showing that only the southern area was influenced by the internal Gavrovo thrusting, which produced more restricted conditions in this area.

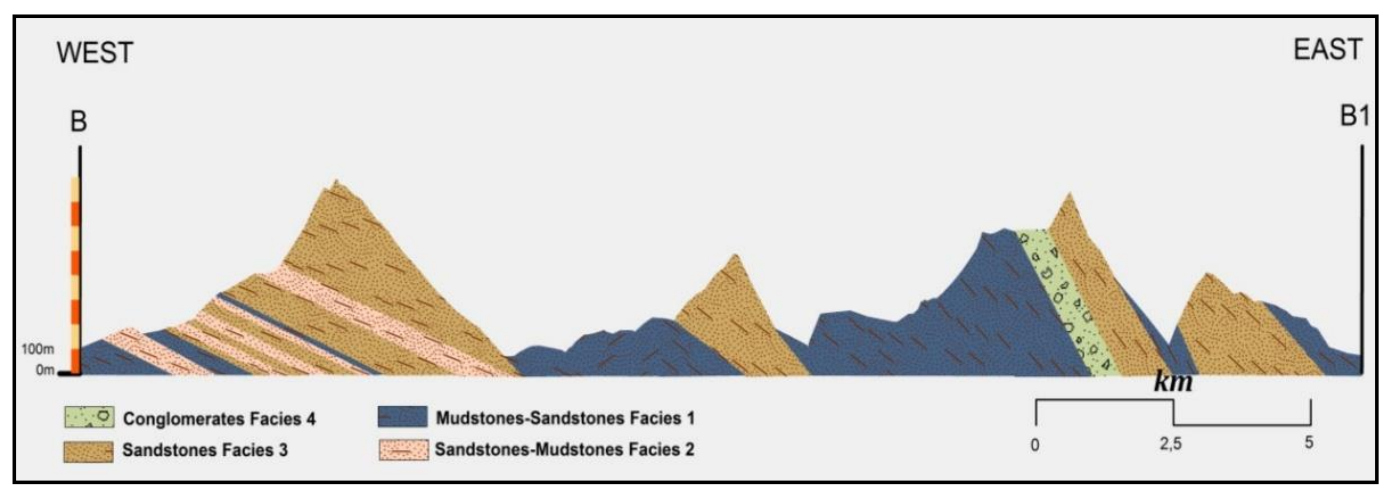

Figure 7 - Section north of the Evinos river. For location see figure 2.

The presence of high deformed outer fans in the northern area (Fig. 7) and in relation with the presence of inner fan deposits over outer fans in this area introduce a strong influence of the northern area from the internal Ionian thrust.

Due to Gavrovo thrust activity Klokova and Varasova Mountains were formed and Cretaceous basement was outcropped (Fig. 8), but only in the area south of Evinos River, whereas due to internal Ionian Thrust activity Arakinthos Mountain with submarine fans, north of Evinos River, was deformed; whereas this activity is not outcropped south of Evinos River.

The palaeocurrent regime showed that during Oligocene the activity of Gavrovo and Internal Ionian thrusts produced restricted narrow sub-basins in different phase and paleoflows changed from a westward direction (in an open basin) to axial trends (in the restricted conditions) during the sedimentation. 


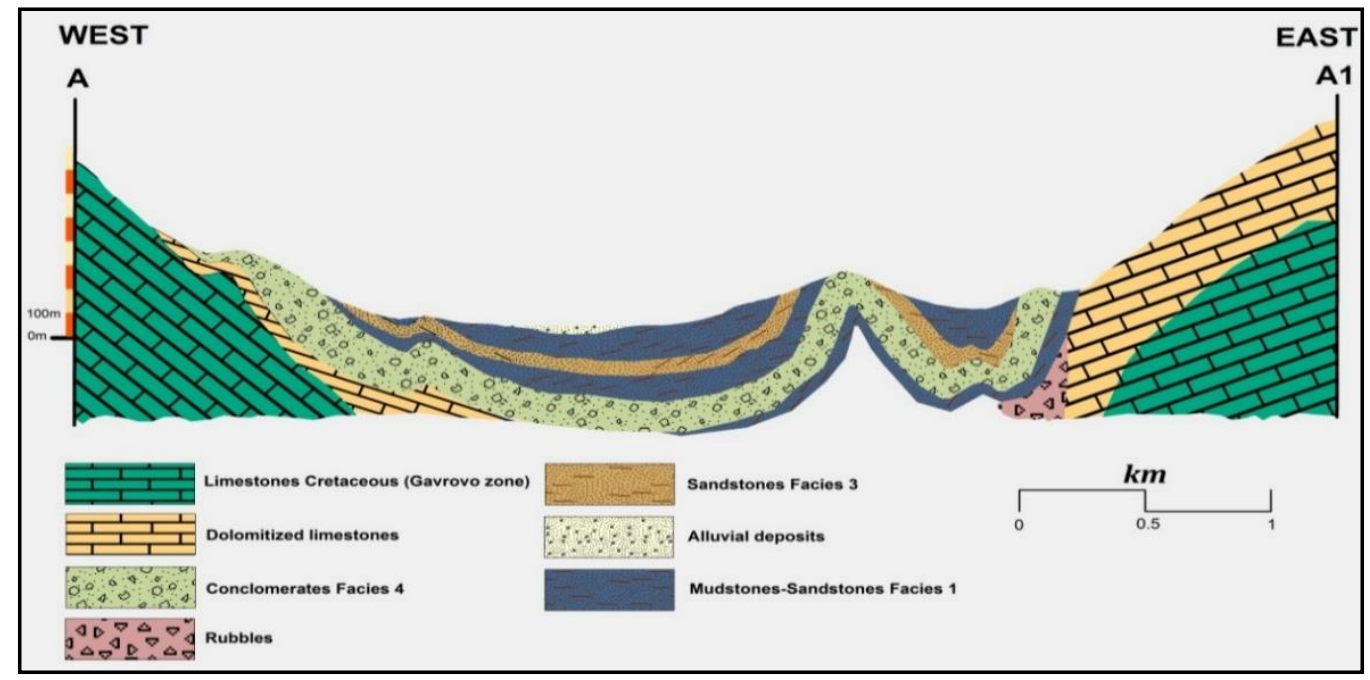

Figure 8 - Section south of the Evinos river. For location see figure 2.

From the above, in the studied part of the Pindos foreland, it seems that Evinos River probably flows on a previous strike-slip zone, acted during the sedimentation of submarine fans. Due to this strikeslip fault zone different depositional conditions were produced south and north of Evinos River. This strike-slip fault zone cross-cut both internal thrusts (Gavrovo and internal Ionian) and acted as the major pathway for the sediment transportation in more distal parts (Fig. 9).

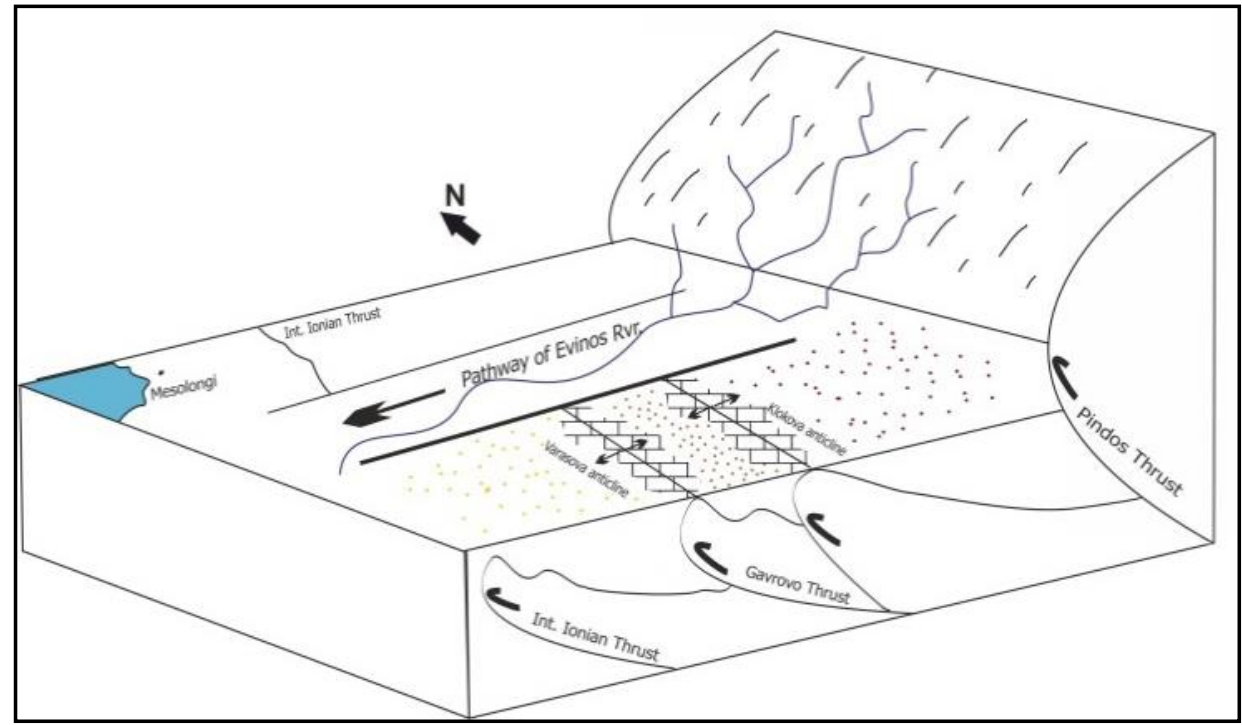

Figure 9 - Possible schematic tectonic model of the study area, depicting Evinos pathway.

\section{References}

Avramidis, P., Zelilidis, A. and Kontopoulos, N., 2000. Thrust Dissection Control of Deep Water Clastic Dispersal Patterns in the Klematia - Paramythia Foreland Basin, Western Greece, Geological Magazine, 137, 667-685.

Avramidis, P. and Zelilidis, A., 2001. The nature of deep-marine sedimentation and palaeocurrent trends as an evidence of Pindos foreland basin fill conditions, Episodes, 24, No4, 252-256. 
Avramidis, P., Zelilidis, A., Vakalas, I. and Kontopoulos, N., 2002. Interactions between tectonic activity and eustatic sea-level changes in the Pindos foreland and Mesohellenic piggy-back basins, NW Greece: Basin evolution and hydrocarbon potential, Journal of Petroleum Geology, 25, 1, 53-82.

Konstantopoulos P., Maravelis A. and Zelilidis A., 2013. The implication of transfer faults in foreland basin evolution: Application on Pindos Foreland Basin, West Peloponnesus, Greece, Terra Nova, 25, 323-336.

Vakalas, I., Ananiadis, G., Mpourlokas, J., Poulimenos, D., Getsos, K., Pantopoulos, G., Avramidis, P., Zelilidis, A. and Kontopoulos, N., 2001. Paleocurrent directions as an indicator of Pindos foreland evolution (central and southern part), Western Greece, Bull. Geol. Soc. Greece, XXXVI/2, 785-791.

Vakalas, I. and Zelilidis, A., 2002. How does the presence of intrabasinal highs and the differential time activity of the Pindos thrust controls the formation of deep marine clastic reservoirs in the Pindos Foreland, Greece, AAPG Intern. Conf. and Exhib., October 27-30, Egypt, Extended abstract 76.

Vakalas, I., Ananiadis, G., Zelilidis, A., Kontopoulos, N. and Tsikouras, B., 2004. Provenance of Pindos foreland flysch deposits using scanning electron microscopy and microanalysis, Bull. Geol. Soc. Greece, XXXVI/1, 607-614.

Zelilidis, A., Maravelis, A.G., Tserolas, P. and Konstantopoulos, P.A., 2015. An overview of the Petroleum systems in the Ionian zone, onshore NW Greece and Albania, J. Petr. Geol., 38(3), 331-347.

IGME, 1971. Sheet Nafpaktos, scale 1:50.000.

IGME, 1977. Sheet Thermon, scale 1:50.000.

IGME, 1985. Sheet Klepa, scale 1.50:000.

IGME, 1991. Sheet Evinokhorion, scale 1:50.000.

IGME, 1996. Sheet Messolonghion, scale 1:50.000. 